University of Nebraska - Lincoln

DigitalCommons@University of Nebraska - Lincoln

$10-2011$

\title{
Toxic effects and bioaccumulation of nano-, micron- and ionic-Ag in the polychaete, Nereis diversicolor
}

\author{
Yi Cong \\ Roskilde University, Roskilde, Denmark, cong@ruc.dk \\ Gary T. Banta \\ Roskilde University, Roskilde, Denmark, banta@ruc.dk \\ Henriette Selck \\ Roskilde University, hse@virgil.ruc.dk \\ Deborah Berhanu \\ Natural History Museum, London, d.berhanu@nhm.ac.uk \\ Eugenia Valsami-Jones \\ Natural History Museum, London, e.valsami-jones@nhm.ac.uk
}

See next page for additional authors

Follow this and additional works at: https://digitalcommons.unl.edu/biosciforbes

Part of the Pharmacology, Toxicology and Environmental Health Commons

Cong, Yi; Banta, Gary T.; Selck, Henriette; Berhanu, Deborah; Valsami-Jones, Eugenia; and Forbes, Valery E., "Toxic effects and bioaccumulation of nano-, micron- and ionic-Ag in the polychaete, Nereis diversicolor" (2011). Valery Forbes Publications. 39.

https://digitalcommons.unl.edu/biosciforbes/39

This Article is brought to you for free and open access by the Papers in the Biological Sciences at DigitalCommons@University of Nebraska - Lincoln. It has been accepted for inclusion in Valery Forbes Publications by an authorized administrator of DigitalCommons@University of Nebraska - Lincoln. 


\section{Authors}

Yi Cong, Gary T. Banta, Henriette Selck, Deborah Berhanu, Eugenia Valsami-Jones, and Valery E. Forbes 


\title{
Toxic effects and bioaccumulation of nano-, micron- and ionic-Ag in the polychaete, Nereis diversicolor
}

\author{
Yi Cong, ${ }^{1}$ Gary T. Banta, ${ }^{1}$ Henriette Selck, ${ }^{1}$ Deborah Berhanu, ${ }^{2}$ \\ Eugenia Valsami-Jones, ${ }^{2}$ Valery E. Forbes ${ }^{3}$
}

\author{
1. Department of Environmental, Social and Spatial Change (ENSPAC), Roskilde University, Universitetsvej 1, \\ PO Box 26o, 400o Roskilde, Denmark (cong@ruc.dk ; banta@ruc.dk ; selck@ruc.dk ) \\ 2. Department of Mineralogy, Natural History Museum, London SW7 5BD, UK (d.berhanu@nhm.ac.uk ; \\ e.valsami-jones@nhm.ac.uk) \\ 3. School of Biological Sciences, University of Nebraska-Lincoln, 348 Manter Hall, Lincoln, NE 68588-o118, USA \\ (vforbes3@unl.edu) \\ Corresponding author - Y. Cong, tel 45 46742568, fax 45 46743041,
}

\begin{abstract}
There is increasing concern about the toxicities and potential risks, both still poorly understood, of silver nanoparticles for the aquatic environment after their eventual release via wastewater discharges. In this study, the toxicities of sediment associated nano $(<100 \mathrm{~nm})$-, micron $(2-3.5 \mu \mathrm{m})$ - and ionic $\left(\mathrm{AgNO}_{3}\right)$-Ag on the sediment-dwelling polychaete, Nereis diversicolor, were compared after 10 days of sediment exposure, using survival, DNA damage (comet assay) and bioaccumulation as endpoints. The nominal concentrations used in all exposure scenarios were o, 1, 5, 10, 25, and $50 \mu \mathrm{g} \mathrm{Ag} / \mathrm{g}$ dry weight (dw) sediment. Our results showed that Ag was able to cause DNA damage in Nereis coelomocytes, and that this effect was both concentrationand Ag form-related. There was significantly greater genotoxicity (higher tail moment and tail DNA intensities) at 25 and 50 $\mu \mathrm{g} / \mathrm{g} \mathrm{dw}$ in nano- and micron-Ag treatments and at $50 \mu \mathrm{g} / \mathrm{g} \mathrm{dw}$ in the ionic-Ag treatment compared to the controls (o $\mu \mathrm{g} / \mathrm{g}$ $\mathrm{dw})$. The nano-Ag treatment had the greatest genotoxic effect of the three tested $\mathrm{Ag}$ forms, and the ionic-Ag treatment was the least genotoxic. $N$. diversicolor did accumulate sediment-associated Ag from all three forms. Ag body burdens at the highest exposure concentration were $8.56 \pm 6.63,6.92 \pm 5.86$ and $9.86 \pm 4.94 \mu \mathrm{g} / \mathrm{g} \mathrm{dw}$ for worms in nano-, micron- and ionic-Ag treatments, respectively, but there was no significant difference in $\mathrm{Ag}$ bioaccumulation among the three treatments.
\end{abstract}

Keywords: silver nanoparticles, marine invertebrate, sediment exposure, genotoxicity, Ag body burden

\section{Introduction}

Silver nanoparticles (Ag NPs) of size less than $100 \mathrm{~nm}$ are of concern due to their increasing use in consumer products which may pose risks for the environment and human health. Ag NPs have properties that are different from their bulk counterparts, exhibiting higher reactivity partly due to their relatively large surface area, but also potentially due to size-related quantum effects. Applications using Ag NPs have therefore become widespread in fields such as bio-sensing, the food industry, water purification, and medical sciences (Klaine et al., 2008). Ag NP-containing products, such as odor resistant textiles, food packaging, cosmetics, household appliances, and medical devices may release Ag particles (nanoparticles or aggregates) or $\mathrm{Ag}^{+}$ions via wastewater discharge into the aquatic environment (Benn and Westerhoff, 2008). Thus, aquatic organisms are particularly likely to be exposed to these metal contaminants, and aggregation and precipitation of Ag NPs in aquatic systems suggest that benthic species may be especially at risk.
Though still limited, an increasing number of studies concerning Ag NP effects on aquatic organisms under laboratory conditions have been published in recent years (reviewed by Fabrega et al., 2011), making more data available regarding their bioavailability, bioaccumulation and toxicities. Zhao and Wang (2010) demonstrated the uptake of Ag NPs in Daphnia magna from both water and dietary routes, and found that more than $70 \%$ of Ag NPs accumulated in the daphnids was through the ingestion of algae. Ag NPs were also shown to be taken up by aquatic vertebrates, such as zebrafish (Danio rerio) embryos and liver tissue, fathead minnow (Pimephales promelas) embryos, rainbow trout (Oncorhynchus mykiss) gill and carp (Cyprius carpio), and existed within the body in both single and agglomerated forms (Choi et al., 2010; Farkas et al., 2011; Gaiser et al., 2009; Laban et al., 2010; Lee et al., 2007a, 2007b). Uptake of Ag NPs was also observed in mammalian cell lines, and the particles distributed throughout the cytoplasm, nuclei, lysosomes, endosomes, as well as deposited in mitochondria (Asharani et al., 2009; Hsin et al., 2008; Kim et al., 2009). Ag NPs are able to 
induce several kinds of sublethal phenotypic abnormalities and cause physiological dysfunction of aquatic vertebrate embryos during development (Asharani et al., 2008; Laban et al., 2010; Lee et al., 2007a, 2007b; Ringwood et al., 2010; Wu et al., 2010). Recent studies have also demonstrated cytotoxic and genotoxic effects of Ag NPs, including biomembrane damage (Arora et al., 2008, 2009; Carlson et al., 2008; Farkas et al., 2010, 2011; Hussain et al., 2005), mitochondrial dysfunction (Farkas et al., 2010) and ROS-dependent oxidative stress (Carlson et al., 2008; Choi et al., 2010; Hussain et al., 2005; Kim et al., 2009), DNA damage and chromosomal aberrations (Asharani et al., 2009; Choi et al., 2010; Kim et al., 2009; Wise et al., 2010), apoptosis (Arora et al., 2008; Asharani et al., 2008; Choi et al., 2010; Park et al., 2010) and inflammation (Carlson et al., 2008; Cha et al., 2008; Park et al., 2010), which have been observed in different cell types. In addition, it was reported that $\mathrm{Ag}^{+}$ions could be released from Ag NPs by oxidation (Ho et al., 2010) and contributed to the observed toxicities (Navarro et al., 20o8). Distinguishable toxic fingerprints of $\mathrm{Ag} \mathrm{NPs}$ and $\mathrm{AgNO}_{3}$ have been demonstrated in Japanese medaka (Oryzias latipes) liver (Chae et al., 2009) and zebrafish (D. rerio) embryos (Asharani et al., 2008), indicating different toxic mechanisms involved for these two Ag forms.

Ag NPs have properties that are different from micron-Ag and $\mathrm{Ag}^{+}$ions. The inclusion of both "bulk" and ionic forms of $\mathrm{Ag}$ in comparison with Ag NPs is of importance to decipher if effects are driven by the small size of NPs, or other characteristics (e.g., ion release) of these particles. Nevertheless, most existing research on Ag NPs to date focuses on comparison of toxicities among different Ag NPs or between the particulate and ionic form of Ag, and few studies have directly compared nano-sized versus micron-sized Ag. These studies have also primarily included exposure from the water phase, despite the fact that most nanoparticulate metals released to the aquatic environment will accumulate in the sediment compartment. The sediment exposure route has received little attention. Furthermore, despite an increasing number of in vitro studies concerning the toxic effects of Ag NPs on vertebrates (particularly freshwater fish and mammalian cell lines), there is a serious lack of information about their in vivo toxicities and toxicities to aquatic invertebrates. It is essential to include aquatic invertebrates as test organisms under relevant exposure conditions for environmental pollution studies because they represent key species in the transformation, detoxification and cycling of environmentally relevant contaminants discharged into aqueous environments (Cattaneo et al., 2009; Ratte, 1999). The sediment-dwelling ragworm, Nereis diversicolor, is known to play a crucial role in the fate of chemicals in estuarine areas as a consequence of its relative tolerance and its influence on metal speciation and aromatic hydrocarbon transformation in sediment through bioturbation, particle mixing and irrigation (Banta and Andersen, 2003; Berthet et al., 2003; François et al., 2002; Mouneyrac et al., 2003). N. diversicolor is thus an appropriate test organism for examining the fate and effects of metal NPs in sediment systems.

The purpose of our study was to compare toxic effects of nano-, micron- and ionic-Ag mixed into sediment on $N$. diversicolor using survival and cellular DNA damage as endpoints, as well as to measure $\mathrm{Ag}$ bioaccumulation in worm tissue as a result of 10 days of sediment exposure.

\section{Materials and methods}

\subsection{Animal collection and culturing}

$N$. diversicolor adults, with an average length of 5-7 cm and an average wet weight of $0.3 \mathrm{~g}$, were collected from Roskilde Fjord near shore $\left(55^{\circ} 40.710\right.$ ? $\mathrm{N}, 11^{\circ} 59.120$ ? $\left.\mathrm{E}\right)$ during winter of $2009(\mathrm{o}-4$ $\left.{ }^{\circ} \mathrm{C}\right)$ and spring of $2010\left(4-6{ }^{\circ} \mathrm{C}\right)$. After transferring to the laboratory, the worms were placed in natural sediment (collected from the same site, sieved $<1 \mathrm{~mm}$ ) to acclimatize for 5-8 days with aerated natural seawater (the same site, $15 \%$ o salinity). A stepwise increase of temperature by $3-4{ }^{\circ} \mathrm{C}$ every 3 days from ambient temperature up to $15{ }^{\circ} \mathrm{C}$ was applied during the acclimatization period. Eventually, the natural seawater was replaced with filtered natural seawater $(<0.2 \mu \mathrm{m}, 15 \%)$ and worms acclimatized for another two days. One day before exposure, all worms were carefully picked out of the sediment and placed in clean filtered seawater to depurate their guts overnight. During the acclimation and exposure periods, worms were fed natural sieved sediment without additional food supply.

\subsection{Characterization of nano- and micron-Ag}

Silver nanoparticles (<100 nm, cat.\# 576832, 99.5\% metals basis, coated by $0.2 \mathrm{wt} \%$ PVP) and micron-sized particles $(2-3.5 \mu \mathrm{m}$, cat.\# 32,708-5, $\geq 99.9 \%$ trace metal basis) were purchased from Sigma-Aldrich (Steinheim, Germany). The identification of crystal structure of both particles was performed on the powder, as received, using X-ray diffraction (XRD). Data were collected using a Nonius PSD 120 powder diffraction system equipped with a position sensitive detector. The characterization of hydrodynamic diameter (suspended particle size) and zeta potential (particle surface charge, an indication of suspension stability) was only carried out on nano-Ag. Stock Ag NP suspension (nominal concentration of $0.5 \mathrm{~g} / \mathrm{L}$ ) was prepared in deionized water (18.2 $\Omega$, Millipore) and ultrasonicated (8o W, $45 \mathrm{kHz}$ ) in a water bath (Ultrasonic Bath VWR, Lutterworth, UK) for $15 \mathrm{~min}$ followed by a $15 \mathrm{~min}$ pause. This process was repeated 4 times (total time: $2 \mathrm{~h}$ ), and the final suspension was analyzed using a Zetasizer Nano ZS (Malvern Zetasizer Nano ZS, Malvern, UK). Original particle size and morphology of both Ag particles were visually assessed by a Hitachi $\mathrm{H}-7100$ transmission electron microscopy (TEM) operating at 100 $\mathrm{kV}$. Micron-Ag suspension in deionized water was unstable as expected due to the large size of the microparticles. However, the sample was composed of microparticles as well as nanoparticles. Further analysis was therefore carried out in toluene. Micron-Ag was therefore suspended in toluene, ultrasonicated at $100 \mathrm{~W}$ and $30 \mathrm{kHz}$ with a probe sonicator (Hielscher UP1ooH, Teltow, Germany) for $30 \mathrm{~s}$ before imaging. Afterwards, a drop of Ag suspension was left to dry at room temperature on a carbon coated copper grid for later TEM imaging.

\subsection{Sediment exposure}

Sandy sediment for all treatments was collected from Roskilde Fjord (Denmark) at the same site as worms. The top few centimeters of the sediment surface were scraped off and sieved to less than $1 \mathrm{~mm}$ in the field with natural seawater $(15 \%$, $\mathrm{pH}$ around 8.o). After transferring to the laboratory, the overlying seawater was removed, and the sediment was rinsed once by mixing with filtered natural seawater. After settling, the overlying water was carefully removed, and six aliquots of sediment (around $1 \mathrm{~g}$ ) were taken out for detection of background Ag concentration by Graphite Furnace Atomic Absorption Spectrometry (GFAAS, GTA 120, Varian, Australia). Briefly, the sediment samples were lyophilized (Christ Alpha 1-2, Osterode, Germany) at around $-50{ }^{\circ} \mathrm{C}$ overnight. Afterwards, the sediments were transferred to Weflon tubes, weighed and digested with $65 \% \mathrm{HNO}_{3}$ in a microwave oven (Milestone MLS-120o Mega, Leutenkirch, Germany). The digestion program was $250 \mathrm{~W}, 400 \mathrm{~W}, 650 \mathrm{~W}$ and $250 \mathrm{~W}$ for $6 \mathrm{~min}$, respectively. After cooling, the digested suspension was neutralized by adding $25 \%$ ammonium solution (Merck, Darmstadt, Germany) and filtered before GFAAS measurement (performed within a few hours). Standard Ag solutions (Inorganic Ventures, Christiansburg, VA, USA) (o, 2, 4, 8, 16 and $32 \mu \mathrm{g} / \mathrm{L}$ ) were used to calibrate Ag concentrations ( $\mu \mathrm{g} / \mathrm{g} \mathrm{dw})$. Another six aliquots of sediment (around $5 \mathrm{~g}$ ) were taken for $\mathrm{dw} / \mathrm{ww}$ ratio and organic 
content measurements. All the remaining sediment was kept at 4 ${ }^{\circ} \mathrm{C}$ for no more than one week before spiking and no more than two weeks before the start of exposure.

The stock suspensions/solution and stock sediment (nominal concentration of $100 \mu \mathrm{g} \mathrm{Ag} / \mathrm{g} \mathrm{dw}$ ) of the three $\mathrm{Ag}$ forms were prepared as follows. For Ag NPs, two bottles of stock suspension were prepared by adding $0.5 \mathrm{~g}$ powder to $1 \mathrm{~L}$ deionized water; the two bottles were sonicated as described previously. Afterwards, 1.6 L suspension was added to sediment and homogenized. For ionic-Ag, 0.944 g $\mathrm{AgNO}_{3}$ (cat.\# S-6506, Sigma-Aldrich, Steinheim, Germany) were dissolved in a small amount of $65 \% \mathrm{HNO}_{3}$ (Merck, Darmstadt, Germany), and deionized water was added to a final volume of $2 \mathrm{~L}$. After mixing, 1.6 L solution was added to sediment and homogenized as for Ag NPs. Due to the poor dispersion of micron-Ag in deionized water by sonication (pilot study), its stock suspension was prepared by adding $0.48 \mathrm{~g}$ particles to $1.6 \mathrm{~L}$ deionized water which was stirred with a magnetic stirrer for $15 \mathrm{~min}$, and all the suspension was added immediately into sediment and homogenized. It is likely that the changes in speciation of silver may occur upon mixing with sediment particles but for the sake of simplicity we refer to the different treatments according to the initial silver form added to the sediment namely nano-Ag, micron-Ag and ionic-Ag, respectively, throughout the text.

Exposure concentrations (nominal concentrations of o, 1, 5, $10,25,50 \mu \mathrm{g} / \mathrm{g} \mathrm{dw}$ ) of the three Ag forms were obtained by homogeneously mixing stock sediment with clean sediment. The measured Ag concentrations of stock and exposure sediment were analyzed using Flame Atomic Absorption Spectrometry (FAAS, SpectrAA-220, Varian, Australia) and GFAAS (as before). In addition, PVP-controls (o.1 $\mu \mathrm{g} \mathrm{PVP} / \mathrm{g}$ dw sediment) were prepared by homogeneously mixing a solution of PVP into sediment in the same way as for the different Ag treatments. The PVP concentration corresponded to that in the highest Ag NP exposure group ( $50 \mu \mathrm{g} \mathrm{Ag} / \mathrm{g} \mathrm{dw}$ ), and was used to observe if there was a genotoxic effect from the PVP coating alone.

All experimental plastic beakers were acid washed $(20 \%$ $\mathrm{HNO}_{3}$ ) and rinsed once with seawater before exposure. Following overnight depuration, individual worms were transferred to a beaker containing around $320 \mathrm{~g}$ wet sediment of the appropriate $\mathrm{Ag}$ concentration and form and $600 \mathrm{~mL}$ filtered natural seawater. Sediment exposure was conducted in the dark at $15{ }^{\circ} \mathrm{C}$ for 10 days. The overlying seawater was changed 2 times during the 10 days of exposure to get rid of worm waste products. We measured the Ag concentration in the sediment after exposure in a similarly designed pilot study and found that $<0.1 \%$ of $\mathrm{Ag}$ was lost to the water in our exposure systems. Beakers and air supply were inspected daily. Mortality and growth in all treatments were recorded after 10 days of sediment exposure.

\subsection{Comet assay procedure}

The comet assay was based on the protocol of Singh et al. (1998) and Rank and Jensen (2003), and the procedure for extraction of Nereid coelomocytes described by De Boeck and Kirsch-Volders (1997) and Lewis and Galloway (2008), with some modifications. Three to five replicates (one individual is one replicate) for each exposure concentration were used in the comet assay. A positive control (worms from o $\mu \mathrm{g} \mathrm{Ag/g} \mathrm{dw}$, but extracted cells exposed to ultraviolet light) was established as a comparison with the control (o $\mu \mathrm{g} \mathrm{Ag/g} \mathrm{dw)} \mathrm{in} \mathrm{each} \mathrm{Ag-form} \mathrm{treatment.} \mathrm{PVP-con-}$ trols were used to observe if there was a genotoxic effect from the PVP coating alone.

After 10 days of exposure, worms were carefully picked out of the sediment and allowed to depurate their guts in natural filtered seawater overnight. Afterwards, 30-50 $\mu \mathrm{L}$ coelomic fluid of $N$. diversicolor was gently extracted into $50 \mu \mathrm{L}$ PBS (137 mM $\mathrm{NaCl}, 2.68 \mathrm{mM} \mathrm{KCl}, 1.75 \mathrm{mM} \mathrm{KH}_{2} \mathrm{PO}_{4}, 8.1 \mathrm{mM} \mathrm{Na}_{2} \mathrm{HPO}_{4}, \mathrm{pH} 7.4$ ) for each assay by carefully inserting a $1 \mathrm{~mL}$ syringe fitted with a $0.4 \mathrm{~mm} \times 20 \mathrm{~mm}$ needle (chilled prior to use) into the posterior region of the worm (avoiding the gut) and stored on ice briefly before use. Coelomic fluid mixed with PBS was then gently centrifuged (Allegra X-15R centrifuge, Beckman Coulter, Inc., USA) at $300 \times g, 4{ }^{\circ} \mathrm{C}$ for $5 \mathrm{~min}$, and the supernatant was removed. The cell pellet (i.e., the concentrated coelomic cells) was gently mixed with $125 \mu \mathrm{L}$ of $0.65 \%$ low melting point (LMP) agarose (Invitrogen, Paisley, UK), and $100 \mu \mathrm{L}$ of the mixture was added to a fully frosted slide (one individual per slide) precoated with a $100 \mu \mathrm{L}$ layer of $0.8 \%$ normal melting point (NMP) agarose (Invitrogen, Paisley, UK). Another $100 \mu \mathrm{L}$ of $0.65 \%$ LMP agarose was then coated as the third layer. The agarose solutions used for the coelomocytes were dissolved in Kenny's salt solution (200 mM $\mathrm{NaCl}, 9 \mathrm{mM} \mathrm{KCl}, 0.7 \mathrm{mM} \mathrm{K} \mathrm{HPO}_{4}, 2 \mathrm{mM} \mathrm{NaHCO}, \mathrm{pH}$ 8.0) and melted in a microwave oven for $1 \mathrm{~min}$. For each layer, a cover slip was placed upon the gel, and the slides were cooled on ice for 15 min to solidify the gel. Afterwards, all work was carried out under yellow light to avoid UV damage to the DNA.

After having removed the cover slips, the slides used as positive controls were exposed to UV light from a Ren UV C lamp $(253.7 \mathrm{~nm}, 15 \mathrm{~W}$, Sylvania, Japan) for $20 \mathrm{~s}$. Then all the slides were placed in lysis solution (2.5 M NaCl, o.1 M EDTA, $10 \mathrm{mM}$ Tris, $1 \%$ Triton $\mathrm{X}-100, \mathrm{pH}$ 10.0) for at least $1.5 \mathrm{~h}$ in the refrigerator. Excess salts were removed by rinsing the slides for $10 \mathrm{~s}$ in electrophoresis solution ( $0.3 \mathrm{M} \mathrm{NaOH}, 1 \mathrm{mM}$ EDTA, $\mathrm{pH}>13$ ). The slides were then placed in the electrophoresis chamber filled with cold electrophoresis solution. Alkaline unwinding was carried out for 40 min followed by 20 min of electrophoresis at $300 \mathrm{~mA}$ and $25 \mathrm{~V}$. Finally, the slides were neutralized twice for $5 \mathrm{~min}$ in $0.4 \mathrm{M}$ Tris solution ( $\mathrm{pH} 7 \cdot 5$ ).

The slides were stained with $80 \mu \mathrm{L}$ ethidium bromide $(20 \mu \mathrm{g} /$ $\mathrm{mL}$ ) for at least $10 \mathrm{~min}$ and examined with a fluorescence microscope ( $50 \times$ oil immersion objective, Dialux $22 \mathrm{~EB}$, Leica, Wetzlar, Germany) with $625 \times$ magnification. On each slide, 50 randomly chosen cell nuclei (obviously apoptotic and necrotic DNA excluded) were examined automatically using software from Kinetic Imaging (Comet assay III). The levels of DNA damage were measured as tail moment, defined as the product of the tail length and the fraction of total DNA in the tail, and tail DNA intensity (\%), expressed as the DNA intensity of the tail compared with the intensity of the whole comet (cell) (Dhawan and Anderson, 2009).

\subsection{Bioaccumulation}

After comet assay, the worms were frozen at $-80{ }^{\circ} \mathrm{C}$ until use. The Ag concentrations in worm tissues were determined using GFAAS. Before digestion of worm tissues, all worms were lyophilized at around $-50{ }^{\circ} \mathrm{C}$ overnight. A pool of 1-2 worms per replicate (three replicates for each concentration) was ground into powder using a mortar and pestle. The resulting powder was digested and analyzed on GFAAS as described for sediments. We confirmed the validity of our calibration and analysis of tissue metal concentration by analyzing with a certified biological material (lobster hepatopancreas, LUTS-1, NRC Canada) with a known Ag concentration.

\subsection{Statistical analysis}

All data (except PVP control) were analyzed using two-way analysis of variance (two-way ANOVA) followed by planned comparisons using a Bonferroni correction to compare the effects of the three $\mathrm{Ag}$ forms in each concentration and to compare exposure concentrations $(1,5,10,25,50 \mu \mathrm{g} / \mathrm{g} \mathrm{dw})$ to the controls for each $\mathrm{Ag}$ form. A two sample $t$-test was performed to compare the effect of PVP on DNA damage with that of Ag NPs. Data were tested for normality and homogeneity before analysis. Results 
Table 1. Measured sediment exposure concentrations of three Ag treatments at experimental start. Nominal Ag concentrations of the three $\mathrm{Ag}$ treatments were $\mathrm{o}, 1,5,10,25$ and $50 \mu \mathrm{g} / \mathrm{g} \mathrm{dw}$ sed.

\begin{tabular}{lc}
\hline Form & Measured concentration $(\mu \mathrm{g} / \mathrm{g} \mathrm{dw})(\mathrm{SD})$ \\
\hline Nano-Ag $(<100 \mathrm{~nm})$ & $0.025(0.06), 0.64(0.13), 2.98(0.04), 7.04$ \\
$(0.39), 25.96(0.90), 46.87(2.82)$ \\
Micron-Ag $(2-3.5 \mu \mathrm{m})$ & $0.025(0.06), 0.26(0.08), 1.68(0.38), 8.63$ \\
$(1.66), 22.73(6.03), 47.34(7.84)$ \\
$\mathrm{AgNO}_{3}\left(\mathrm{Ag}^{+}\right)$ & $0.025(0.06), 0.37(0.04), 2.33(0.23), 4.83$ \\
& $(0.12), 19.30(1.60), 41.63(1.94)$ \\
\hline
\end{tabular}

are expressed as mean \pm 1 standard deviation (SD) $\left(n=3^{-5}\right.$ for comet assay, $n=3$ for bioaccumulation). Differences were considered statistically significant at $p \leq 0.05$. All statistical analyses were performed using SYSTAT 13.0 software (Chicago, IL, USA).

\section{Results}

\subsection{Characterization of nano- and micron-Ag}

Crystal structure, original particle size and shape of nano- and micron-Ag were characterized by XRD and TEM. For Ag NPs, the XRD pattern corresponds to silver (Figure $1 \mathrm{~A}, 1$ ), and no other material was detected. The presence of highly crystalline material was observed (Figure $1 \mathrm{~A}$, arrow), suggesting the presence of large Ag particles (aggregates) in the primary manufacture. For micron-Ag, the XRD pattern also corresponds to Ag (Figure $1 \mathrm{~A}, 2)$. However, approximately $5-10 \%$ of non-crystalline material was observed, suggesting that it was not as pure as described by the manufacturer ( $\geq 99.9 \%$ trace metal basis). The TEM image exhibits polyhedral Ag NPs with a size distribution ranging from approximately 20 to $200 \mathrm{~nm}$ (Figure $1 \mathrm{~B}$ and C). However, micron-Ag was found containing both micron- and nano-sized particles as shown in Figure $1 \mathrm{D}$ and E. Preparation of micron-Ag suspension in toluene further demonstrated polydispersed Ag particles with different shapes (Figure ${ }_{1 F}$ ) and a wide size distribution ranging from $8 \mathrm{~nm}$ to $3 \mu \mathrm{m}$ (Figure $1 G$ ). Hydrodynamic diameter and zeta potential of nano-Ag were characterized by DLS. The average hydrodynamic diameter of Ag NPs in stock suspension prepared by ultrasonication was $162 \pm 4 \mathrm{~nm}$ (Figure $1 \mathrm{H}$ ), and the obtained suspension was very stable, as confirmed by the zeta potential value of $-49 \pm 0.75 \mathrm{mV}$.

\subsection{Sediment properties}

The dw/ww ratio of natural sandy sediment was $0.78(n=6)$, the organic matter content (OMC) was $0.56 \%(n=6)$ and the background $\mathrm{Ag}$ concentration was $0.025 \mu \mathrm{g} / \mathrm{g} \mathrm{dw}(n=6)$. Measured concentrations of stock sediment $(n=3)$ were 115,80 and $75 \mu \mathrm{g}$ $\mathrm{Ag} / \mathrm{g} \mathrm{dw}$ for nano-, micron- and ionic-Ag, respectively. Measured sediment exposure concentrations $(n=3)$ of the three Ag forms compared to nominal concentrations are shown in Table 1. At nominal concentrations of 10,25 and $50 \mu \mathrm{g} / \mathrm{g} \mathrm{dw}$, the actual concentrations in ionic-Ag spiked sediment were slightly lower $(12-38 \%)$ than in nano- and micron-Ag treatments. At nominal concentrations of 1 and $5 \mu \mathrm{g} / \mathrm{g} \mathrm{dw}$, the actual concentrations in micron-Ag spiked sediment were somewhat lower (37-49\%) than in nano-and ionic-Ag treatments. Generally, the measured exposure concentrations at the start of the experiment were close to the nominal concentrations, and we did establish a concentration range spanning nearly 2 orders of magnitude.
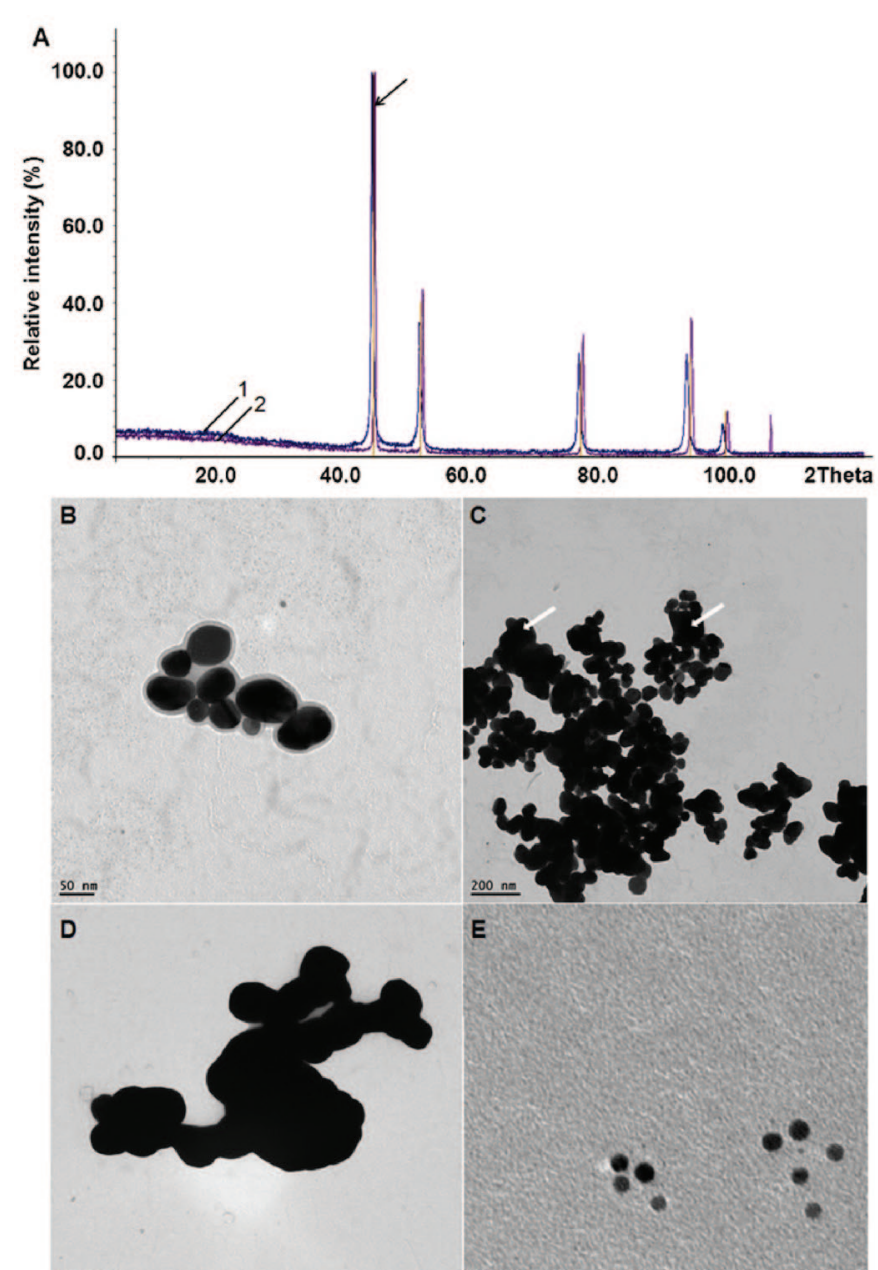

E

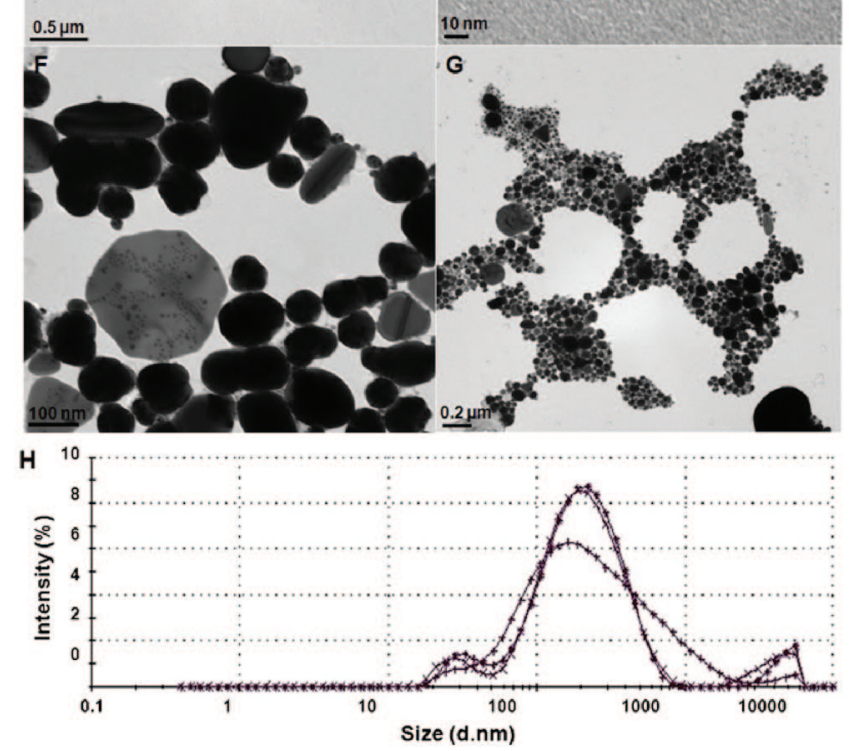

Figure 1. Characterization of nano-and micron-Ag particles. (A) XRD pattern of nano-Ag (1) and micron-Ag (2) particles. The arrow represents the presence of highly crystalline material. TEM images of (B) high magnification and (C) low magnification of Ag NPs (white arrows refer to the particles with size up to $200 \mathrm{~nm}$ ); (D and E) micron-Ag contains both micron- and nano-sized particles (prepared in deionized water); ( $F$ and $G$ ) further demonstrated particle types (size and shape) of micron-Ag by suspending samples in toluene and ultrasonicating with a probe for $30 \mathrm{~s}$. (H) DLS of hydrodynamic size distribution of Ag NPs expressed by intensity (three replicate analyses are shown). 


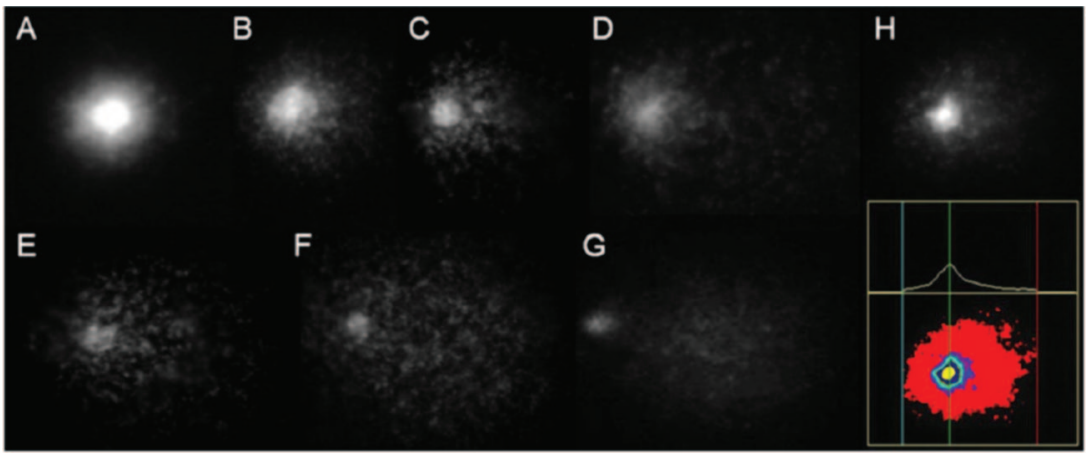

Figure 2. Image from comet assay showing different extents of DNA damage of $N$. diversicolor coelomocytes after Ag exposure (625× magnification). (A) Control (undamaged cell nucleus); (B-F) an increasing DNA damage of coelomocytes typical with less compactness and weaker brightness in the head and increasing DNA fractions around the head shown as a tail (more damaged DNAs with increasing Ag exposure concentrations); $(\mathrm{G})$ positive control (worms from o $\mu \mathrm{g} \mathrm{Ag} / \mathrm{g} \mathrm{dw}$, but extracted cells exposed to UV light) with tiny and obscure heads and a mass of DNA fractions accumulated in the tail (the tail also has a distance away from the head); $(\mathrm{H})$ an example of analysis of a DNA image (upper panel) by the comet assay III software (lower panel). Blue line: the start of the comet; green line: the center of the head; red line: the end of the tail. Diameter of undamaged nucleus is approximately $5-8 \mu \mathrm{m}$.

\subsection{Mortality and growth}

Three worms were found dead after 10 days of sediment exposure, one in each Ag form-treated group, and there were no concentration-dependent mortality or growth effects. The worms did not differ in their growth or have any significant weight loss in any of the Ag treatments after exposure.

\subsection{DNA damage}

$N$. diversicolor coelomocytes exposed to Ag showed increased DNA damage with increasing exposure concentration (Figures 2 and 3). The values of tail moment and tail DNA intensity (\%), which are two commonly used measures of DNA damage, showed no significant difference among the three control treatments (o $\mu \mathrm{g} \mathrm{Ag/g} \mathrm{dw)} \mathrm{(} p \leq 1.000$ and $p \leq 1.000$, respectively) or among the in vitro positive control groups $(p \leq 1$.0oo and $p \leq$ 1.0oo, respectively) (Figure $3 \mathrm{~A}$ and $\mathrm{B}$ ). The in vitro positive controls exhibited significantly higher tail moment and tail DNA intensities compared to the control treatments as expected, however (Figure $3 \mathrm{~A}$ and $\mathrm{B}$ ). In PVP-control treatments, no significant difference in tail moment ( $p \leq 0.863)$ or tail DNA intensity $(p \leq$ o.974) was observed compared to the nano-Ag control (i.e., o $\mu$ g $\mathrm{Ag} / \mathrm{g} \mathrm{dw}$ ) (data not shown).

The results of tail moment and tail DNA intensity both showed a form- and concentration-related genotoxicity of Ag (Table 2). Additionally, Ag form and concentration interacted significantly to affect tail moment whereas the interaction effect was marginal for tail DNA intensity (Table 2). There were significantly higher tail moment and tail DNA intensities (\%) at 25 and $50 \mu \mathrm{g} / \mathrm{g} \mathrm{dw}$ in nano- and micron-Ag treated groups and at 50 $\mu \mathrm{g} / \mathrm{g} \mathrm{dw}$ in the ionic-Ag treated group compared to the controls (o $\mu \mathrm{g} / \mathrm{g} \mathrm{dw})$ (Figure 3A and B). At the highest exposure concentration of $50 \mu \mathrm{g} / \mathrm{g} \mathrm{dw}$, nano-Ag treated worms had significantly higher tail moment than micron- and ionic-Ag treatments

Table 2. Effects of Ag form, concentration and their interaction on DNA damage and bioaccumulation by two-way ANOVA.

\begin{tabular}{lccc}
\hline Endpoints & \multicolumn{2}{l}{$p$-Value } & \\
\cline { 2 - 4 } & Ag form & Concentration & Ag form*Concentration \\
\hline Tail moment & 0.003 & $<0.001$ & 0.001 \\
Tail DNA intensity & 0.038 & $<0.001$ & 0.095 \\
Bioaccumulation & 0.652 & $<0.001$ & 0.901 \\
\hline
\end{tabular}
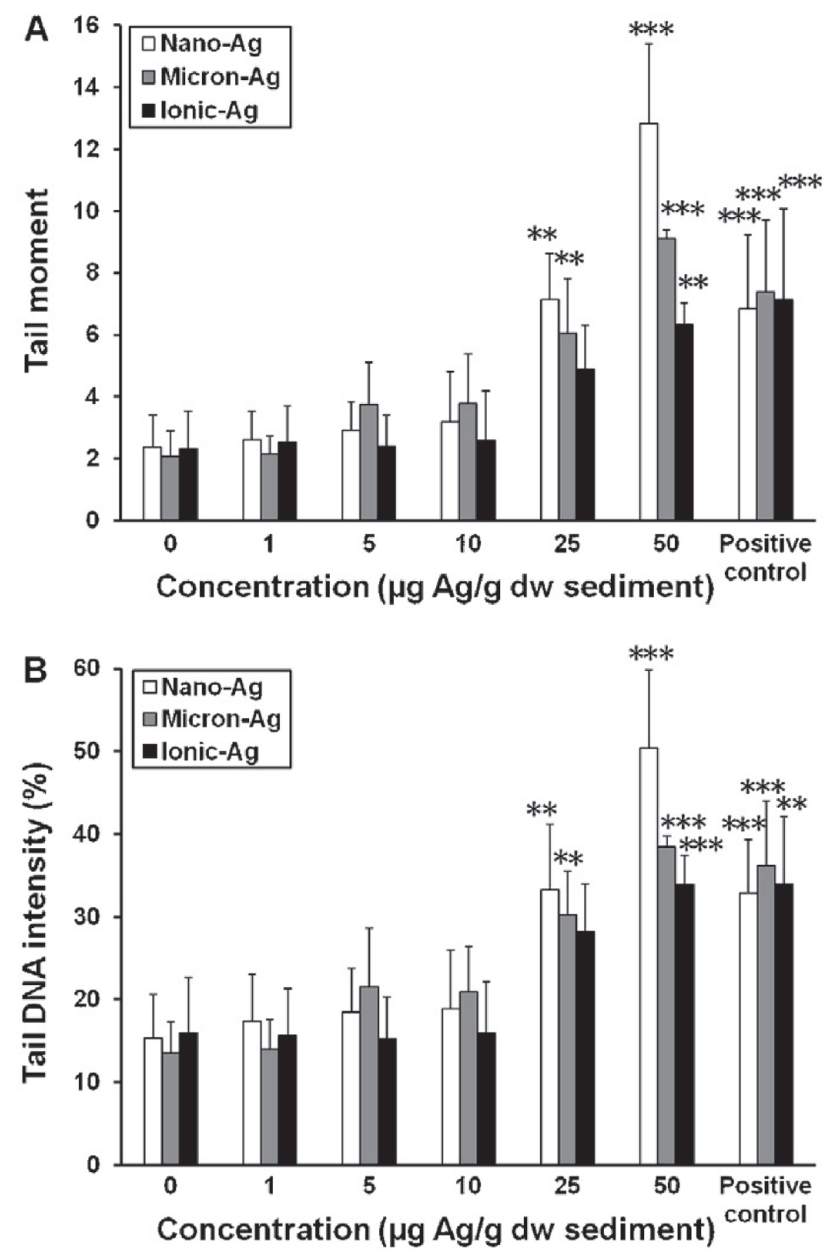

Figure 3. DNA damage of $N$. diversicolor coelomocytes after 10 days of sediment exposure to nano (<100 $\mathrm{nm})$-, micron $(2-3.5 \mu \mathrm{m})$ - and ionic $\left(\mathrm{AgNO}_{3}\right)$-Ag treatments. (A) Tail moment, defined as the product of the tail length and the fraction of total DNA in the tail. (B) Tail DNA intensity (\%), expressed as the DNA intensity of the tail compared with the intensity of the whole comet (cell). The positive control represents worms from o $\mu \mathrm{g} \mathrm{Ag} / \mathrm{g} \mathrm{dw}$, but extracted cells exposed to UV light. Bars represent the mean \pm SD $(n=3-5)$. ${ }^{* *}, * * *$ Significantly different effects of concentrations on DNA damage ( $p<0.01$ and $p<0.001$, respectively) in each Ag-treated group compared to the control (o $\mu \mathrm{g} / \mathrm{g} \mathrm{dw})$. 


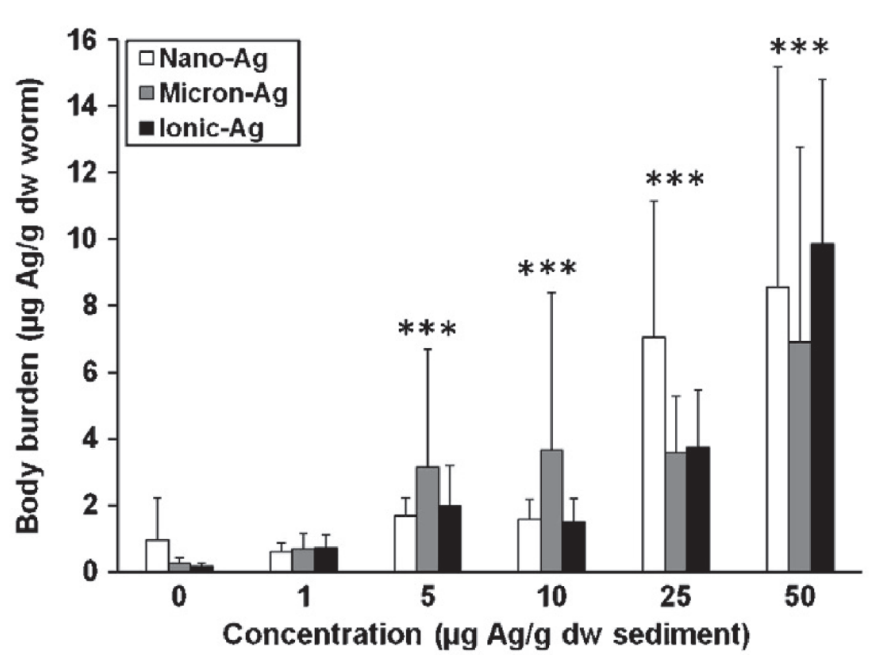

Figure 4. Ag body burdens in $N$. diversicolor after 10 days of sediment exposure to nano $(<100 \mathrm{~nm})$-, micron $(2-3.5 \mu \mathrm{m})$ - and ionic $\left(\mathrm{AgNO}_{3}\right)$ $\mathrm{Ag}$ treatments. Bars represent the mean $\pm \mathrm{SD}(n=3) .{ }^{* * *}$ Significant differences in body burdens of $\mathrm{Ag}(p<0.001)$ for exposure concentrations compared to the control (o $\mu \mathrm{g} / \mathrm{g} \mathrm{dw})$. Note: There was no significant difference among $\mathrm{Ag}$ forms (Table 2); therefore the test of concentration effects was for all three forms together.

( $p<0.05$ and $p<0.001$, respectively). Similarly, the tail DNA intensity also showed significantly higher tail DNA intensities (\%) in nano-Ag treated worms than in ionic-Ag treated worms at 50 $\mu \mathrm{g} / \mathrm{g} \mathrm{dw}(p<0.01)$. Despite a trend of higher tail DNA intensity in nano-Ag treated worms compared to the micron-Ag treated group, this effect was not statistically significant $(p \leq 0.173)$.

\subsection{Ag body burden}

Silver was bioavailable in all three Ag treatments and was accumulated in $N$. diversicolor. Ag body burden increased significantly with increasing exposure concentration (Figure 4). No significant difference in Ag body burden among the three Ag treatments at any concentration was observed, however, and there was no interaction effect between Ag form and concentration on bioaccumulation (Table 2). Ag body burdens in worms exposed to 5, 10, 25 and $50 \mu \mathrm{g} / \mathrm{g} \mathrm{dw}$ of three Ag treatments were significantly greater than those of control worms (Figure 4). Ag body burdens at the highest exposure concentration were $8.56 \pm 6.63,6.92 \pm 5.86$ and $9.86 \pm 4.94 \mu \mathrm{g} / \mathrm{g} \mathrm{dw}($ mean $\pm \mathrm{SD})$ for worms in nano-, micronand ionic-Ag treatments, respectively (Figure 4).

\section{Discussion \\ 4.1. Ag characterization}

To relate properties of nanoparticles to their toxicity potential and ensure that results are reproducible and meaningful, accurate characterization and storage of nanoparticles in dispersion media are essential (Jiang et al., 2009; Murdock et al., 2008; Oberdörster et al., 2005; Powers et al., 2006). In our study, zetapotential measurement of Ag NP suspensions $(-49 \pm 0.75 \mathrm{mV})$ suggested that the particles were stable in the dispersion medium (Derjaguin and Landau, 1941). The better dispersion of micron-Ag observed in toluene compared to deionized water suggests that micron-Ag particles are possibly embedded in an organic matrix and behave in a hydrophobic manner. In contrast, the PVP coating of the Ag NPs provides a better suspension in polar solvents (including water). The TEM images demonstrate a clear difference between the manufacturer's information (<100 $\mathrm{nm}$ and $2-3.5 \mu \mathrm{m}$, respectively) and that observed by our investigation (20-200 nm and $8 \mathrm{~nm}-3 \mu \mathrm{m}$, respectively) for both Ag particle sizes. The reasons for the differences are most likely to be batch-to-batch variation or changes in material properties between synthesis and initial characterization and the particular conditions when utilized, which highlights the importance of fully characterizing commercially obtained NPs before performing toxicity tests or other experiments (Scown et al., 2010). However, the state of Ag NPs in sediment after spiking and during exposure still remains unknown due to limitations of existing characterization techniques. The examination of the state and behavior of NPs in a complex compartment, as the sediment, will provide a better understanding and interpretation of the effects of NPs on organisms.

\subsection{Ag toxicity}

Our comet assay results demonstrated that all silver cause DNA damage in $N$. diversicolor coelomocytes regardless of the $\mathrm{Ag}$ form added to the sediment, which is consistent with existing studies of the genotoxicity of Ag particles/ions in different cell systems (Ahamed et al., 2008; Asharani et al., 2009; Cha et al., 2008; Choi et al., 2010; Hidalgo and Dominguez, 1998). Both tail moment (2.1-2.3) and tail DNA intensity (13.5-15.9\%) results of controls (o $\mu \mathrm{g} \mathrm{Ag} / \mathrm{g} \mathrm{dw}$ ) demonstrated similar values with those reported by Asharani et al. (2009) (tail moment of around 0.52.5 in human lung fibroblast cells and glioblastoma cells) and Lewis and Galloway (2008) (\% DNA in the tail of $\sim 13 \%$ in N. diversicolor coelomocytes), respectively. In addition, tail moments in 25 and $50 \mu \mathrm{g} / \mathrm{g} \mathrm{dw} \mathrm{Ag} \mathrm{NP} \mathrm{treatments} \mathrm{(7.2} \mathrm{and} \mathrm{12.8,} \mathrm{respec-}$ tively) after 10 days of sediment exposure had comparable results with those of human glioblastoma cells after $48 \mathrm{~h}$ exposure to 25 and $50 \mu \mathrm{g} / \mathrm{mL}$ (6 and 9, respectively) Ag NPs (6-20 nm in size). Furthermore, Lewis and Galloway (2008) found that 20$40 \%$ DNA was damaged in $N$. diversicolor coelomocytes after $1 \mathrm{~h}$ in vitro exposure to $52 \mathrm{mg} / \mathrm{L}$ genotoxicant methyl methanesulfonate (MMS), which is commonly used as a positive control in the comet assay (Hackenberg et al., 2011). In comparison, tail DNA intensities (\%) of worm coelomocytes were 32.8-36.2 after in vitro exposure to UV in our study, suggesting a comparable genotoxic strength of different genotoxicants.

The nano-Ag treatment in our study had the highest genotoxicity of the three tested $\mathrm{Ag}$ forms, while ionic-Ag treatment tended to be the least genotoxic. This may suggest that there are different toxic mechanisms involved in the occurrence of DNA damage or that there are different degrees of reactivity of silver dependent on the $\mathrm{Ag}$ forms added. $\mathrm{Ag}^{+}$ions have been shown to cause DNA damage by covalently binding with DNA (Hossain and Huq, 2002) and inhibiting DNA synthesis (Hidalgo and Dominguez, 1998) directly. The lower genotoxicity of ionic-Ag in our study may have been due to $\mathrm{Ag}^{+}$ions $\left(\mathrm{AgNO}_{3}\right)$ being complexed by ligands such as chlorides and thiosulphates, which are abundant in sediment. These complexed forms of Ag possibly reduced the amount of free $\mathrm{Ag}^{+}$ions entering the nuclei and interacting with DNA strands, as supported by the study of LeBlanc et al. (1984) which demonstrated less toxicity of complexed forms of $\mathrm{Ag}$ than free $\mathrm{Ag}^{+}$ions to fathead minnows. As for $\mathrm{Ag}$ NPs, some studies have reported genotoxicity of Ag NPs to different cell types (Ahamed et al., 2008; Wise et al., 2010) by both direct and indirect mechanisms. The tendency for Ag NPs to accumulate in the nuclei of zebrafish embryos $\left(5^{-20} \mathrm{~nm}\right)$ and human cancer cells $(6-20 \mathrm{~nm})$ has been described, suggesting that they may lead to genomic damage and chromosomal aberrations (Asharani et al., 2008, 2009) directly. On the other hand, it has been suggested that Ag NPs entering cells disrupt the mitochondrial respiratory chain leading to the production of ROS and the 
interruption of ATP synthesis, which in turn cause DNA damage (Asharani et al., 2009). Additionally, the potential release of $\mathrm{Ag}^{+}$ions from particle surfaces is also a possible mechanism by which Ag NPs exert toxicity to nuclei. Ag NPs may dissolve or degrade under oxidative conditions, and this process is affected by $\mathrm{pH}$, temperature, organic matter and surface coatings (Ho et al., 2010; Liu and Hurt, 2010; Luoma, 2008). Although the Ag NPs used in our study had a PVP coating, it has been demonstrated that the oxidative dissolution of Ag NPs in the presence of PVP can occur (Ho et al., 2010) and the released $\mathrm{Ag}^{+}$ions contribute to the NP toxicities (Navarro et al., 2008). However, the genotoxicity of Ag NPs observed in our study cannot be solely attributed to $\mathrm{Ag}^{+}$ion release, as a greater genotoxic effect was demonstrated in nano- than in ionic-Ag treatments. Further investigations are needed to determine the kinetics of oxidative dissolution of $\mathrm{Ag}$ NPs under sediment exposure scenarios. For micron-sized Ag particles, few studies have reported their genotoxicity, and the mechanisms still remain unclear. The actual size of micron-Ag used in our study covers a wide range from nano- to micronsize, with most particles falling outside of the nanometer range. Hence, although there was an overlap in size distribution between our micron-Ag and nano-Ag, different gentoxicities were observed possibly due to the size effect as the majority of Ag NPs were within the nano size range. The smaller nano-sized particles contained in the micron-Ag may have entered nuclei and interacted with DNA strands. For larger Ag particles contained in the micron-Ag, phagocytosis and encapsulation (large particles are surrounded by large numbers of coelomocytes) by coelomocytes may have facilitated the uptake of bulk micron-Ag, as well as agglomerated nanoparticles, both of which processes may have contributed to the observed genotoxicity. However, cell internalization is not always essential for toxicity, as interactions of particles at the cell surface (even in agglomerated form) may also cause toxicity (Johnston et al., 2010). Additionally, the release of $\mathrm{Ag}^{+}$ions could be another contributor to micron-Ag toxicity but we would expect a lower releasing rate and smaller amount of ions due to a smaller fraction of surface atoms and less susceptibility to oxidation due to their higher redox potential compared to NPs (Ho et al., 2010; Pal et al., 1997). Clearly, more work is needed to elucidate the mechanisms by which different forms of $\mathrm{Ag}$ (i.e., what metal species are present in the sediment after addition of the three Ag forms, respectively) cause genotoxicity to $N$. diversicolor.

Bioaccumulation of NPs in organisms is another issue which has received relatively little attention. Our bioaccumulation results demonstrated that silver is bioavailable to $N$. diversicolor regardless of the Ag form added, possibly through their ingestion of Ag-associated particles in sediment during feeding, or through body surface contact during burrowing. Ag body burdens were $8.56 \pm 6.63,6.92 \pm 5.86$ and $9.86 \pm 4.94 \mu \mathrm{g} / \mathrm{g} \mathrm{dw}$ at the highest exposure concentration for worms in nano-, micronand ionic-Ag treatments, respectively. These correspond to BAF factors of $0.17,0.14$ and 0.20 , respectively, if one assumes the worms were in "steady state" with their exposure media (i.e., sediment). While this assumption undoubtedly is not true, the approximate BAF values do indicate that, while the worms are exposed to and take up Ag; they do not accumulate it to any great degree. Furthermore, it is noteworthy that there were no significant differences in the degree to which $N$. diversicolor accumulated silver among treatments; despite expected differences in reactivity and chemical behavior of the three different forms of $\mathrm{Ag}$ and thus the potential uptake routes. In previous field studies, Ag body burdens observed in $N$. diversicolor were $0.1-36.4$ $\mu \mathrm{g} / \mathrm{g} \mathrm{dw}$ when background $\mathrm{Ag}$ concentrations in sediment were

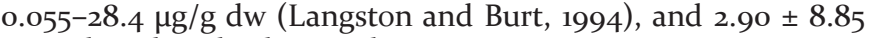
$\mu \mathrm{g} / \mathrm{g} d \mathrm{dw}$ when background Ag concentrations were $1.15 \pm 0.11$ $\mu \mathrm{g} / \mathrm{g} \mathrm{dw}$ (Rainbow et al., 2009), respectively. In laboratory studies, Ag concentrations in $N$. diversicolor exposed to 3.4, 11 and 34 $\mu \mathrm{g} / \mathrm{L}$ Ag were $2.5 \pm 0.9,3.4 \pm 2.1,5.0 \pm 2.1 \mu \mathrm{g} / \mathrm{g} \mathrm{dw}$ after 5 days of exposure (Mouneyrac et al., 2003), respectively, indicating similar levels of bioaccumulation (i.e., BAF $=0.15-2.52$ ) as we observed at our highest concentrations. As for Ag NPs, a few studies have reported their bioaccumulation in freshwater fish after water exposure. Choi et al. (2010) demonstrated that Ag concentrations in liver tissue of zebrafish $(D$. rerio) after treatment with 30 and $120 \mathrm{mg} / \mathrm{L} \mathrm{Ag} \mathrm{NPs} \mathrm{(2-30} \mathrm{nm} \mathrm{in} \mathrm{diameter)} \mathrm{for} 24 \mathrm{~h}$ were 0.29 and $2.4 \mathrm{ng} \mathrm{Ag} / \mathrm{mg}$ liver, respectively. In rainbow trout (O. mykiss), different sizes of Ag particles were found to be accumulated differently in tissues after 10 days of water exposure. Ag NPs (10 nm, $100 \mu \mathrm{g} / \mathrm{L}$ ) were found to be highly concentrated within both gills $(0.61 \pm 0.07 \mu \mathrm{g} / \mathrm{g}$ tissue $)$ and liver $(1.50 \pm 0.30$ $\mu \mathrm{g} / \mathrm{g}$ tissue), while micron-Ag particles (o.6-1.6 $\mu \mathrm{m}, 100 \mu \mathrm{g} / \mathrm{L}$ ) were most highly concentrated in the liver $(1.63 \pm 0.18 \mu \mathrm{g} / \mathrm{g}$ tissue) (Scown et al., 2010). In summary, the existing bioaccumulation data suggest substantial variation in Ag body burden, which is likely not only due to differences in exposure pathways, concentrations and media conditions among studies, but also to differences within and among species.

Generally, N. diversicolor is tolerant of heavy metal exposure, especially $\mathrm{Cu}, \mathrm{Zn}$ and Cd (Bryan and Hummerstone, 1971, 1973; Grant et al., 1989; Hateley et al., 1989; Mouneyrac et al., 2003), and is able to control its body concentration of certain metals by the induction of physiological detoxification mechanisms, involving the formation of metal-containing extracellular granules, mineralized lysosomes, excretion of metals by exocytosis via coelomocytes, and synthesis and turnover of metal binding proteins, such as metallothioneins (MTs) (Bryan and Hummerstone, 1977; Fernandez and Jones, 1989; Mouneyrac et al., 2003; $\mathrm{Ng}$ et al., 2008; Poirier et al., 2006). The lower approximate BAF values and the lack of difference in $\mathrm{Ag}$ body burden among $\mathrm{Ag}$ treatments observed in our study may suggest that detoxification mechanisms are triggered by the presence of $\mathrm{Ag}$ in all three treatments in $N$. diversicolor (i.e., regardless of $\mathrm{Ag}$ form added) which can have maintained Ag concentrations in the body at a similar and endurable level. However, the specific detoxification mechanism(s) used by $N$. diversicolor for Ag detoxification, whether the mechanisms differ for different Ag forms, how they are triggered, where and in what form Ag will distribute in cells and the extent to which different Ag forms are excreted all still need further investigation.

It is currently considered that different mechanisms are involved in the uptake and toxicity of $\mathrm{Ag}^{+}$ions and $\mathrm{Ag}$ NPs. Uptake and toxicity of $\mathrm{Ag}^{+}$ions is mainly via competition with $\mathrm{Na}^{+}$and ATP-dependent transport and disruption of membrane sodium channels, as well as the depletion of the cellular energy system (Bianchini and Wood, 2003; Bury and Wood, 1999; Bury et al., 1999; Galvez and Wood, 2002; Hidalgo and Dominguez, 1998; Pedroso et al., 2007). In contrast, Ag NPs are taken up by cells through diffusion (Lee et al., 2007a, 2007b), pinocytosis (Luoma, 2008) and phagocytosis (Park et al., 2010), as well as via disturbance of membrane components. Once taken up, Ag NPs can lead to toxicities via mechanisms such as ROS-dependant oxidative stress followed by cytotoxicity and genotoxicity, a Trojanhorse type mechanism (Ag NPs act as a carrier to deliver free silver ions into the cell) (Lubick, 2008; Luoma, 2008; Park et al., 2010), as well as synergistic effects of NPs and released $\mathrm{Ag}^{+}$ions. However, further studies are needed to elucidate the toxic mechanisms of different $\mathrm{Ag}$ forms in aquatic invertebrates using a wider variety of cellular bio-indicators, such as membrane damage, subcellular distribution, reactive oxygen species (ROS) production and anti-oxidative enzyme activities, which have been indicated to be involved in toxicity, at least for Ag NPs, in mammalian cell lines and some aquatic vertebrates. Our results suggest that there should be focus on detoxification mechanisms of different forms of $\mathrm{Ag}$, especially given these known differences in uptake and internal effects. 


\section{Conclusions}

Comet assay results demonstrated that all three $\mathrm{Ag}$ forms when added to sediment to which $N$. diversicolor were exposed can cause DNA damage and that, this effect is both Ag form- and concentration-related, with silver added as Ag NPs being most toxic and ionic-Ag being least toxic and also indicating that DNA damage is a sensitive endpoint in $N$. diversicolor exposed to Ag. Different reactivity or mechanisms are possibly involved in the DNA damage caused by the three Ag treatments (forms added), and genotoxicity of Ag NPs cannot be solely attributed to the release of $\mathrm{Ag}^{+}$ions. Ag body burden in worms increased with increasing exposure concentration. However, there was no significant difference in body burden among the three Ag forms after 10 days of exposure. Further studies should be directed to characterize Ag NPs in the sediment compartment (i.e., including Ag speciation) and investigate their uptake routes, mechanisms of toxicity and detoxification mechanisms in aquatic invertebrates.

Acknowledgements - This work was supported by Roskilde University (RUC) and is done in cooperation with the EU NanoReTox project (7th Framework Programme, Grant Agreement no. CP-FP 2144782). The authors gratefully acknowledge Anne-Grete Winding, Klara Jensen, Anja Holden Damsholt, Anne Busk Faarborg and Rikke Guttesen for their technical guidance and assistance during experiments. Support from the China Scholarship Council (CSC) is also gratefully acknowledged.

\section{References}

Ahamed et al., 2008 - M. Ahamed, M. Karns, M. Goodson, J. Rowe, S. M. Hussain, J. J. Schlager, and Y. Hong, DNA damage response to different surface chemistry of silver nanoparticles in mammalian cells. Toxicol. Appl. Pharmacol., 233 (2008), pp. 404-410.

Arora et al., 2008 - S. Arora, J. Jain, J. M. Rajwade, and K. M. Paknikar, Cellular responses induced by silver nanoparticles: in vitro studies. Toxicol. Lett., 179 (2008), pp. 93-100.

Arora et al., 2009 • S. Arora, J. Jain, J. M. Rajwade, and K. M. Paknikar, Interactions of silver nanoparticles with primary mouse fibroblasts and liver cells. Toxicol. Appl. Pharmacol., 236 (2009), pp. 310-318.

Asharani et al., 2008 - P. V. Asharani, Y. L. Wu, Z. Y. Gong, and S. Valiyaveettil, Toxicity of silver nanoparticles in zebrafish models. Nanotechnology, 19 (2008), pp. 255102-2255107.

Asharani et al., 2009 - P. V. Asharani, G. Low Kah Mun, M. P. Hande, and S. Valiyaveettil, Cytotoxicity and genotoxicity of silver nanoparticles in human cells. ACS Nano, 3 (2009), pp. 279-290.

Banta and Andersen, 2003 - G. Banta and O. Andersen, Bioturbation and the fate of sediment pollutants-experimental case studies of selected infauna species. Vie Milieu, 53 (2003), pp. 233-248.

Benn and Westerhoff, 2008 - T. M. Benn and P. Westerhoff, Nanoparticle silver released into water from commercially available sock fabrics. Environ. Sci. Technol., 42 (2008), pp. 7025-7026.

Berthet et al., 2003 • B. Berthet, C. Mouneyrac, J. C. Amiard, C. AmiardTriquet, Y. Berthelot, A. Le Hen, O. Mastain, P. S. Rainbow, and B. D. Smith, Accumulation and soluble binding of cadmium, copper and zinc in the polychaete Hediste diversicolor from coastal sites with different trace metal bioavailabilities. Arch. Environ. Contam. Toxicol., 45 (2003), pp. 468-478.

Bianchini and Wood, 2003 A. Bianchini and C. M. Wood, Mechanism of acute silver toxicity in Daphnia magna. Environ. Toxicol. Chem., 22 (2003), pp. 1361-1367.

Bryan and Hummerstone, 1971 • G. W. Bryan and L. G. Hummerstone, Adaptation of the polychaete Nereis diversicolor to estuarine sediments containing high concentrations of heavy metals. I. General observations and adaptation to copper. J. Mar. Biol. Assoc. U. K., 51 (1971), pp. 845-863.

Bryan and Hummerstone, 1973 • G. W. Bryan and L. G. Hummerstone, Adaptation of the polychaete Nereis diversicolor to estuarine sediments containing high concentrations of zinc and cadmium. J. Mar. Biol. Assoc. U. K., 53 (1973), pp. 839-857.

Bryan and Hummerstone, $1977^{\circ}$ G. W. Bryan and L. G. Hummerstone, Indicators of heavy-metal contamination in the Looe Estuary
(Cornwall) with particular regard to silver and lead. J. Mar. Biol. Assoc. U. K., 57 (1977), pp. 75-92.

Bury and Wood, 1999 * N. R. Bury and C. M. Wood, Mechanism of branchial apical silver uptake by rainbow trout is via the proton-coupled Na (+) channel. Am. J. Physiol., 277 (1999), pp. R1385-R1391.

Bury et al., 1999 • N. R. Bury, M. Grosell, A. K. Grover, and C. M. Wood, ATP dependent silver transport across the basolateral membrane of rainbow trout gills. Toxicol. Appl. Pharmacol., 159 (1999), pp. 1-8.

Carlson et al., 20o8 - C. Carlson, S. M. Hussain, A. M. K. Schrand, L. Braydich-Stolle, K. L. Hess, R. L. Jones, and J. J. Schlager, Unique cellular interaction of silver nanoparticles: size-dependent generation of reactive oxygen species. J. Phys. Chem. B, 112 (2008), pp. 13608-13619.

Cattaneo et al., 2009 • A. G. Cattaneo, R. Gornati, M. Chiriva-Internati, and G. Bernardini, Ecotoxicology of nanomaterials: the role of invertebrate testing. Inv. S. J., 6 (2009), pp. 78-97.

Cha et al., 2008 - K. Cha, H. W. Hong, Y. G. Choi, M. J. Lee, J. H. Park, H. K. Chae, G. Ryu, and H. Myung, Comparison of acute responses of mice livers to short-term exposure to nano-sized or micro-sized silver particles. Biotechnol. Lett., 30 (2008), pp. 1893-1899.

Chae et al., 2009 • Y. J. Chae, C. H. Pham, J. Lee, E. Bae, J. Yi, and M. B. $\mathrm{Gu}$, Evaluation of the toxic impact of silver nanoparticles on Japanese medaka (Oryzias latipes). Aquat. Toxicol., 94 (2009), pp. 320-327.

Choi et al., 2010 • J. E. Choi, S. Kim, J. H. Ahn, P. Youn, J. S. Kang, K. Park, J. Yi, and D. Y. Ryu, Induction of oxidative stress and apoptosis by silver nanoparticles in the liver of adult zebrafish. Aquat. Toxicol., 100 (2010), pp. 151-159.

Klaine et al., 2008 • S. J. Klaine, P. J. J. Alvarez, G. E. Batley, T. F. Fernandes, R. D. Handy, D. Lyon, S. Mahendra, M. J. McLaughlin, and J. R. Lead, Nanomaterials in the environment: behavior, fate, bioavailability, and effects. Environ. Toxicol. Chem., 279 (2008), pp. $1825-1851$.

De Boeck and Kirsch-Volders, $1997 \cdot$ M. De Boeck and M. KirschVolders, Nereis virens (Annelida: Polychaeta) is not an adequate sentinel species to assess the genotoxic risk (comet assay) of PAH exposure to the environment. Environ. Mol. Mutagen., 30 (1997), pp. 82-90.

Derjaguin and Landau, 1941 • B. V. Derjaguin and L. D. Landau, Theory of the stability of strongly charged lyophobic sols and of the adhesion of strongly charged particles in solutions of electrolytes. Acta Phys. Chim., 14 (1941), pp. 633-662.

Dhawan and Anderson, 2009 - A. Dhawan and D. Anderson, Comet Assay in Toxicology, Royal Society of Chemistry, Cambridge (2009).

Fabrega et al., 2o11 • J. Fabrega, S. N. Luoma, C. R. Tyler, T. S. Galloway, and J. R. Lead, Silver nanoparticles: behaviour and effects in the aquatic environment. Environ. Int., 372 (2011), pp. 517-531.

Farkas et al., 2010 • J. Farkas, P. Christian, J. A. Gallego-Urrea, N. Roos, M. Hassellöv, K. E. Tollefsen, and K. V. Thomas, Effects of silver and gold nanoparticles on rainbow trout (Oncorhynchus mykiss) hepatocytes. Aquat. Toxicol., 961 (2010), pp. 44-52.

Farkas et al., 2011 • J. Farkas, P. Christian, J. A. Gallego-Urrea, N. Roos, M. Hassellöv, K. E. Tollefsen, and K. V. Thomas, Uptake and effects of manufactured silver nanoparticles in rainbow trout (Oncorhynchus mykiss) gill cells. Aquat. Toxicol., 1011 (2011), pp. 117-125.

Fernandez and Jones, $1989 \cdot$ T. V. Fernandez and N. V. Jones, The distribution of zinc in the body of Nereis diversicolor. Trop. Ecol., 30 (1989), pp. 285-293.

François et al., 2002 • F. François, M. Gérino, G. Stora, J. P. Durbec, and J. C. Poggiale, Functional approach to sediment reworking by galleryforming macrobenthic organisms: modelling and application with the polychaete Nereis diversicolor. Mar. Ecol. Prog. Ser., 229 (2002), pp. 127-136.

Gaiser et al., 2009 B. K. Gaiser, T. F. Fernandes, M. Jepson, J. R. Lead, C. R. Tyler, and V. Stone, Assessing exposure, uptake and toxicity of silver and cerium dioxide nanoparticles from contaminated environments. Environ. Health, 8 Suppl. 1 (2009), p. S2.

Galvez and Wood, $2002 \cdot$ F. Galvez and C. M. Wood, The mechanisms and costs of physiological and toxicological acclimation to waterborne silver in juvenile rainbow trout. J. Comp. Physiol. B, 172 (2002), pp. 587-597.

Grant et al., 1989 • A. Grant, J. G. Hateley, and N. V. Jones, Mapping the ecological impact of heavy metals in the estuarine polychaete $\mathrm{Ne}$ reis diversicolor using inherited metal tolerance. Mar. Pollut. Bull., 20 (1989), pp. 235-238.

Hackenberg et al., 2011 • S. Hackenberg, A. Scherzed, M. Kessler, S. 
Hummel, A. Technau, K. Froelich, C. Ginzkey, C. Koehler, R. Hagen, and N. Kleinsasser, Silver nanoparticles: evaluation of DNA damage, toxicity and functional impairment in human mesenchymal stem cells. Toxicol. Lett., 201 (2011), pp. 27-33.

Hateley et al., 1989 • J. G. Hateley, A. Grant, and N. V. Jones, Heavy metal tolerance in estuarine populations of Nereis diversicolor, J. S. Ryland, P. A. Tyler, Editors, Reproduction, Genetics and Distribution of Marine Organisms. Proc. 23rd Eur. Mar. Biol. Symp. Olsen and Olsen, Fredensborg (1989), pp. 379-385.

Hidalgo and Dominguez, $1998 \cdot$ E. Hidalgo and C. Dominguez, Study of cytotoxicity mechanisms of silver nitrate in human dermal fibroblasts. Toxicol. Lett., 98 (1998), pp. 169-179.

Ho et al., 2010 • C. M. Ho, S. K. Yau, C. N. Lok, M. H. So, and C. M. Che, Oxidative dissolution of silver nanoparticles by biologically relevant oxidants: a kinetic and mechanistic study. Chem. Asian J., 5 (2010), pp. 285-293.

Hossain and Huq, $2002 \cdot$ Z. Hossain and F. Huq, Studies on the interaction between $\mathrm{Ag}^{+}$and DNA. J. Inorg. Biochem., 91 (2002), pp. 398-404.

Hsin et al., 20o8 - Y. H. Hsin, C. F. Chen, S. Huang, T. S. Shih, P. S. Lai, and P. J. Chueh, The apoptotic effect of nanosilver is mediated by a ROS- and JNK-dependent mechanism involving the mitochondrial pathway in $\mathrm{NIH}_{3} \mathrm{~T}_{3}$ cells. Toxicol. Lett., 179 (2008), pp. 130-139.

Hussain et al., 2005 S. M. Hussain, K. L. Hess, J. M. Gearhart, K. T. Geiss, and J. J. Schlager, In vitro toxicity of nanoparticles in BRL $3 \mathrm{~A}$ rat liver cells. Toxicol. In Vitro, 19 (2005), pp. 975-983.

Jiang et al., 2009 • J. Jiang, G. Oberdörster, and P. Biswas, Characterization of size, surface charge, and agglomeration state of nanoparticle dispersions for toxicological studies. J. Nanopart. Res., 11 (2009), pp. $77-89$.

Johnston et al., 2010 • H. J. Johnston, G. Hutchison, F. M. Christensen, S. Peters, S. Hankin, and V. Stone, A review of the in vivo and in vitro toxicity of silver and gold particulates: particle attributes and biological mechanisms responsible for the observed toxicity. Crit. Rev. Toxicol., 4o (2010), pp. 328-346.

Kim et al., 2009 • S. Kim, J. E. Choi, J. Choi, K. H. Chung, K. Park, J. Yi, and D. Y. Ryu, Oxidative stress-dependent toxicity of silver nanoparticles in human hepatoma cells. Toxicol. In Vitro, 23 (2009), pp. 1076-1084.

Laban et al., 2010 • G. Laban, L. F. Nies, R. F. Turco, J. W. Bickham, and M. S. Sepúlveda, The effects of silver nanoparticles on fathead minnow (Pimephales promelas) embryos. Ecotoxicology, 19 (2010), pp. 185-195.

Langston and Burt, 1994 • W. J. Langston and G. R. Burt, Bioindicators of Ag availability in UK estuaries, A. W. Andren, T. W. Bober, Editors , Transport, Fate and Effects of Silver in the Environment. Proc. 2nd Argentum International ConferenceUniversity of Wisconsin-Madison, WI, USA (1994), pp. 125-130.

LeBlanc et al., 1984 - G. A. LeBlanc, J. D. Mastone, A. P. Paradice, B. F. Wilson, H. B. Lockhart, and K. A. Robillard, The influence of speciation on the toxicity of silver to fathead minnow (Pimephalies promelas). Environ. Toxicol. Chem., 3 (1984), pp. 37-47.

Lee et al., 2007a • H. Y. Lee, H. K. Park, and W. M. Lee, A practical procedure for producing silver nanocoated fabric and its antibacterial evaluation for biomedical applications. Chem. Commun., 28 (2007), pp. 2959-2961.

Lee et al., 2007b - K. J. Lee, P. D. Nallathamby, L. M. Browning, C. J. Osgood, and X. H. Xu, In vivo imaging of transport and biocompatibility of single silver nanoparticles in early development of zebrafish embryos. ACS Nano, 1 (2007), pp. 133-143.

Lewis and Galloway, 2008 - C. Lewis and T. Galloway, Genotoxic damage in polychaetes: a study of species and cell-type sensitivities. $\mathrm{Mu}$ tat. Res., 654 (2008), pp. 69-75.

Liu and Hurt, 2010 - J. Y. Liu and R. H. Hurt, Ion release kinetics and particle persistence in aqueous nano-silver colloids. Environ. Sci. Technol., 44 (2010), pp. 2169-2175.

Lubick, 2008 - N. Lubick, Nanosilver toxicity: ions, nanoparticles or both?. Environ. Sci. Technol., 42 (2008), p. 8617.

Luoma, $2008 \cdot$ S. N. Luoma, Silver Nanotechnologies and the Environment: Old Problems or New Challenges? Project on Emerging Nanotechnologies, Woodrow Wilson Centre, Washington, DC, USA (2008).

Mouneyrac et al., $2003 \cdot$ C. Mouneyrac, O. Mastain, J. C. Amiard, C. Amiard-Triquet, P. Beaunier, A. Y. Jeantet, B. D. Simth, and P. S.
Rainbow, Trace-metal detoxification and tolerance of the estuarine worm Hediste diversicolor chronically exposed in their environment. Mar. Biol., 143 (2003), pp. 731-744.

Murdock et al., 2008 - R. C. Murdock, L. Bradydich-Stolle, A. M. Schrand, J. J. Schlager, and S. M. Hussain, Characterization of nanomaterial dispersion in solution prior to in vitro exposure using dynamic light scattering technique. Toxicol. Sci., 101 (2008), pp. 239-253.

Navarro et al., 2oo8 - E. Navarro, F. Piccapietra, B. Wagner, F. Marconi, R. Kaegi, N. Odzak, L. Sigg, and R. Behra, Toxicity of silver nanoparticles to Chlamydomonas reinhardtii. Environ. Sci. Technol., 42 (2008), pp. 8959-8964.

Ng et al., 20o8 - T. Y. T. Ng, P. S. Rainbow, C. Amiard-Triquet, J. C. Amiard, and W. X. Wang, Decoupling of cadmium biokinetics and metallothionein turnover in a marine polychaete after metal exposure. Aquat. Toxicol., 89 (2008), pp. 47-54.

Oberdörster et al., 2005 - G. Oberdörster, A. Maynard, K. Donaldson, V. Castranova, J. Fitzpatrick, K. Ausman, J. Carter, B. Karn, W. Kreyling, D. Lai, S. Olin, N. Monteiro-Riviere, D. Warheit, and H. Yang, Principles for characterizing the potential human health effects from exposure to nanomaterials: elements of a screening strategy. Part. $\mathcal{E}$ Fibre Toxicol., 2:8 (2005).

Pal et al., 1997 ' T. Pal, T. K. Sau, and N. R. Jana, Reversible formation and dissolution of silver nanoparticles in aqueous surfactant media. Langmuir, 13 (1997), pp. 1481-1485.

Park et al., 2010 • E. J. Park, J. Yi, Y. Kim, K. Choi, and K. Park, Silver nanoparticles induce cytotoxicity by a Trojan-horse type mechanism. Toxicol. In Vitro, 24 (2010), pp. 872-878.

Pedroso et al., 2007 M. S. Pedroso, G. L. Pinho, S. C. Rodrigues, and A. Bianchini, Mechanism of acute silver toxicity in the euryhaline copepod Acartia tonsa. Aquat. Toxicol., 82 (2007), pp. 173-180.

Poirier et al., 2006 - L. Poirier, B. Berthet, J. C. Amiard, A. Y. Jeantet, and C. Amiard-Triquet, A suitable model for the biomonitoring of trace metal bioavailabilities in estuarine sediment: the annelid polychaete Nereis diversicolor. J. Mar. Biol. Assoc. U. K., 86 (2006), pp. 71-82.

Powers et al., 2006 - K. W. Powers, S. C. Brown, V. B. Krishna, S. C. Wasdo, B. M. Moudgil, and S. M. Roberts, Research strategies for safety evaluation of nanomaterials. Part VI. Characterization of nanoscale particles for toxicological evaluation. Toxicol. Sci., 90 (2006), pp. 296-303.

Rainbow et al., 2009 P. S. Rainbow, B. D. Smith, and S. N. Luoma, Differences in trace metal bioaccumulation kinetics among populations of the polychaete Nereis diversicolor from metal-contaminated estuaries. Mar. Ecol. Prog. Ser., 376 (2009), pp. 173-184.

Rank and Jensen, $2003 \cdot \mathrm{J}$. Rank and K. Jensen, Comet assay on gill cells and hemocytes from the blue mussel Mitylus edulis. Ecotoxicol. Environ. Safe., 54 (2003), pp. 323-329.

Ratte, $1999 \cdot$ H. T. Ratte, Bioaccumulation and toxicity of silver compounds: a review. Environ. Toxicol. Chem., 18 (1999), pp. 89-108.

Ringwood et al., 2010 - A. H. Ringwood, M. McCarthy, T. C. Bates, and D. L. Carroll, The effects of silver nanoparticles on oyster embryos. Mar. Environ. Res., 69 Suppl. (2010), pp. S49-S51.

Scown et al., 2010 - T. M. Scown, E. Santos, B. D. Johnston, B. Gaiser, M. Baalousha, S. Mitov, J. R. Lead, V. Stone, T. Fernandes, M. Jepson, V. R. Aerle, and C. R. Tyler, Effects of aqueous exposure to silver nanoparticles of different sizes in rainbow trout. Toxicol. Sci., 115 (2010), pp. 521-534.

Singh et al., 1998 - N. P. Singh, M. T. McCoy, R. R. Tice, and E. L. Schneider, A simple technique for quantitation of low-levels of DNA damage in individual cells. Exp. Cell Res., 175 (1998), pp. 184-191.

Wise et al., 2010 • J. P. Wise, Sr., B. C. Goodale, S. S. Wise, G. A. Craig, A. F. Pongan, R. B. Walter, W. D. Thompson, A. K. Ng, A. M. Aboueissa, H. Mitani, M. J. Spalding, and M. D. Mason, Silver nanospheres are cytotoxic and genotoxic to fish cells. Aquat. Toxicol., 97 (2010), pp. 34-41.

Wu et al., 2010 • Y. Wu, Q. F. Zhou, H. C. Li, W. Liu, T. Wang, and G. B. Jiang, Effects of silver nanoparticles on the development and histopathology biomarkers of Japanese medaka (Oryzias latipes) using the partial-life test. Aquat. Toxicol., 100 (2010), pp. 160-167.

Zhao and Wang, 2010 - C. M. Zhao and W. X. Wang, Biokinetic uptake and efflux of silver nanoparticles in Daphnia magna. Environ. Sci. Technol., 44 (2010), pp. 7699-7704. 